\title{
Exploring the gaps between education and pharmacy practice on antimicrobial stewardship: a qualitative study among pharmacists in Qatar [Corrigendum]
}

Nasr ZG, Higazy A, Wilbur K. Adv Med Educ Pract. 2019:10:287-295.

The authors have advised that an additional funding statement should have been included in the "Acknowledgments" section of their paper (page 293). The authors apologize for this error and confirm that the additional funding source does not constitute a conflict of interest in this work, nor affect the work in any way. The corrected details are as follows:

\section{Acknowledgments}

This study was completed with funding from an Internal Student Grant from Qatar University. The publication of this article was funded by the Qatar National Library. The abstract of this paper was presented at the 2018 ACCP Global Conference on Clinical Pharmacy as a poster presentation with interim findings. The poster's abstract was published in "Poster Abstracts" in Journal of the American College of Clinical Pharmacy; DOI: 10.1002/ JAC5.1059.

\section{Publish your work in this journal}

Advances in Medical Education and Practice is an international, peerreviewed, open access journal that aims to present and publish research on Medical Education covering medical, dental, nursing and allied health care professional education. The journal covers undergraduate education, postgraduate training and continuing medical education including emerging trends and innovative models linking education, research, and health care services. The manuscript management system is completely online and includes a very quick and fair peer-review system. Visit http://www.dovepress.com/testimonials.php to read real quotes from published authors. 